\title{
Domino Suzuki-Miyaura cross-coupling and oxidative condensation reaction: an approach towards synthesis of phenanthridine and its analogues
}

\author{
Yasin Nuree and Jayanta K. Ray* \\ Department of Chemistry, Indian Institute of Technology, Kharagpur -721302, India
}

\section{Introduction}

The phenanthridines are very important class nitrogen containing heterocylic compounds and constitute core structure of many natural alkaloids ${ }^{1,2}$ such as trisphaeridine $(\mathbf{F i g} . \mathbf{1}, \mathbf{1})$ and nitidine (Fig. 1, 2) ${ }^{3-22}$. Quarternarybenzo[c]phenanthridine alkaloids (QBA) represented by sanguinarine(SA), chelerythrine (CHE), and fagaronine (FA) (Fig. 1, 3) exhibit antifungal and nematocidal properties. ${ }^{4}, 5,15,18-20,22,23$ These azaheterocyclic compounds also serve as the core structure of broad range of medicinally active molecules showing anti-tumor activity, anti-viral property, anti-neoplastic or mutagenic activity through DNA-intercalation. ${ }^{5}$ Phenanthridines are also utilized for the synthesis of compounds of therapeutic interests such as anticancer platinum complex typified by phenanthriplatin (Fig. 1, 4), ${ }^{24}$ antibacterial, anti-infectives, antprotozoal, antituberculosis, antitrypanosomiasis compounds ${ }^{5,18,19,25-32}$. The phenanthridine ring systems are also used in lockable colorimetric fluorescence molecular switch, PET tracers, and in material science applications ${ }^{4,15,22,33-48}$.

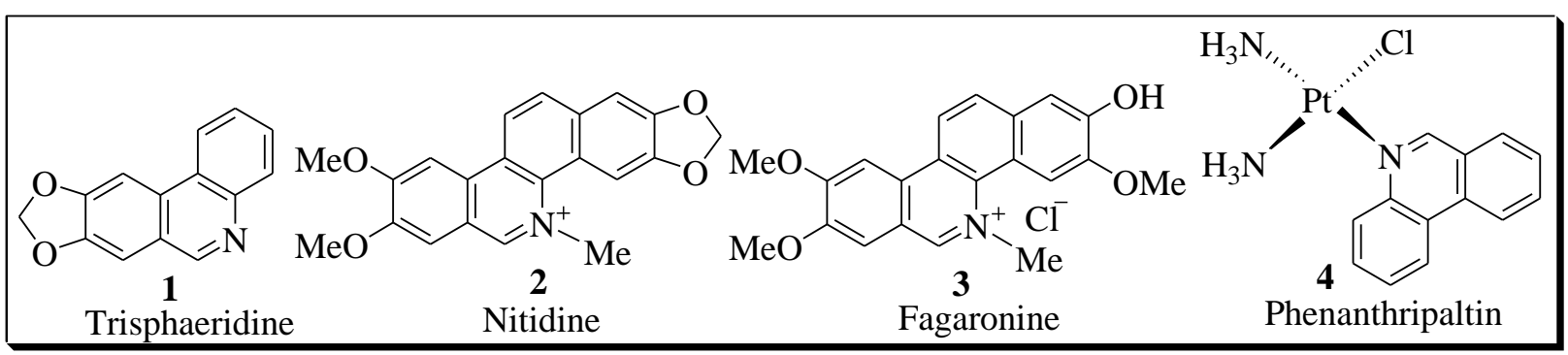

Figure 1. Structure of some bioactive molecules containing phenanthridine unit.

Potential biological activities and functional properties of phenathridines and its derivatives have 
attracted the scientists over the decades towards the synthesis of these molecules. Various methods towards synthesis of these molecules are available in the literature. Recently, a threestep methodology to derive phenathridines via ruthenium catalyzed reactions was reported.

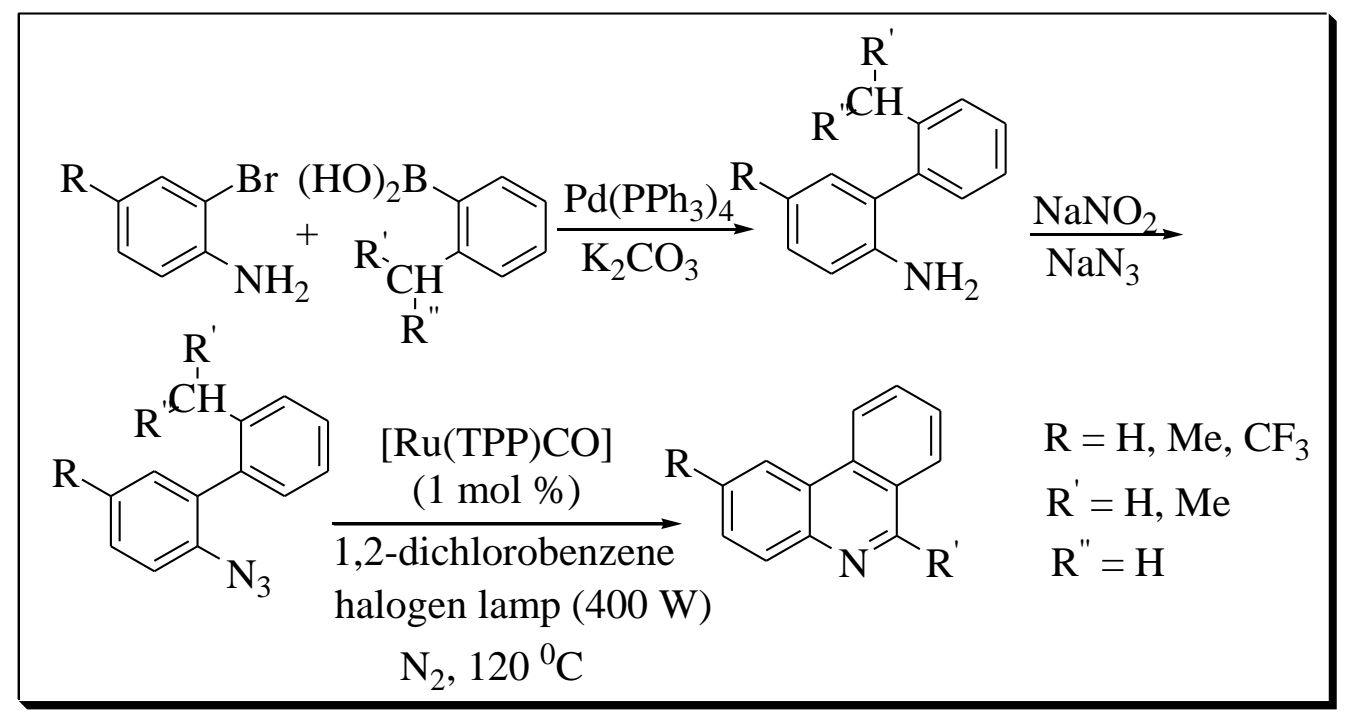

Scheme 1.1. Ruthenium catalyzed synthesis of phenanthridines

Mandal et al. designed a syntheticroute for the development of phenathridines based on azaClaisen rearrangement, ring-closing enyne metathesis and Diels-Alder reaction.

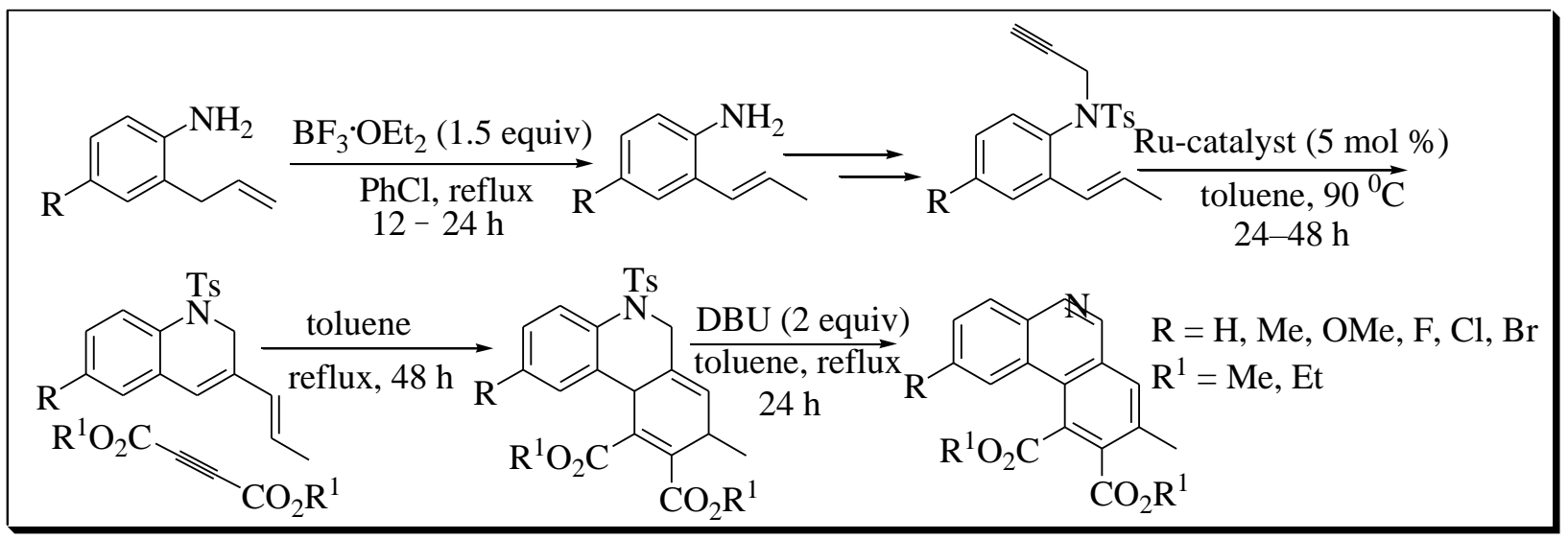

Scheme 1.2. Synthesis of phenanthridines via RCEYM followed and Diels-Alder aromatization 


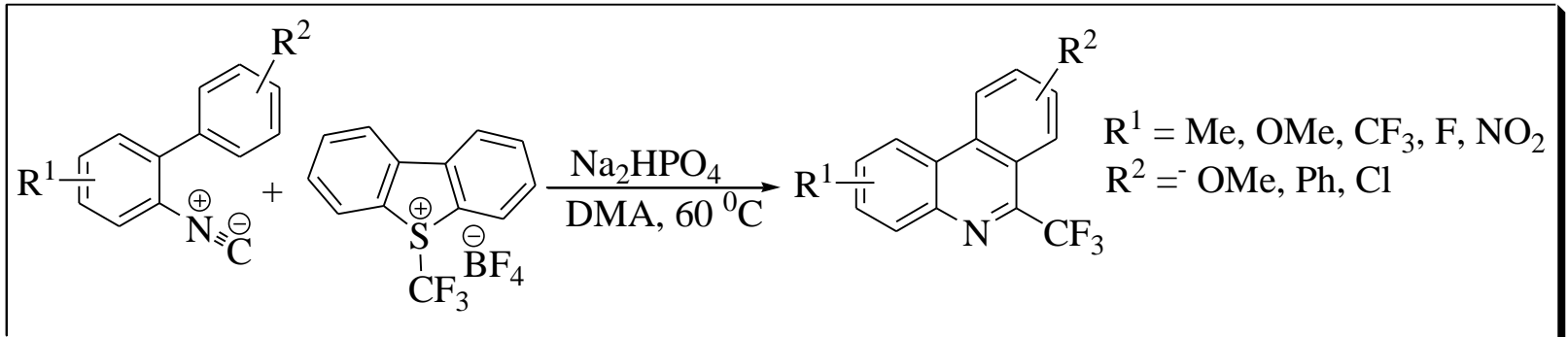

Scheme 1.3. De Novo Synthesisof Trifluoromethylated Phenanthridine Derivatives

Read et al. reported synthesis of phenanthridine derivatives through microwave-mediated cyclization of $o$-furyl(allylamino)arenes ${ }^{49}$.

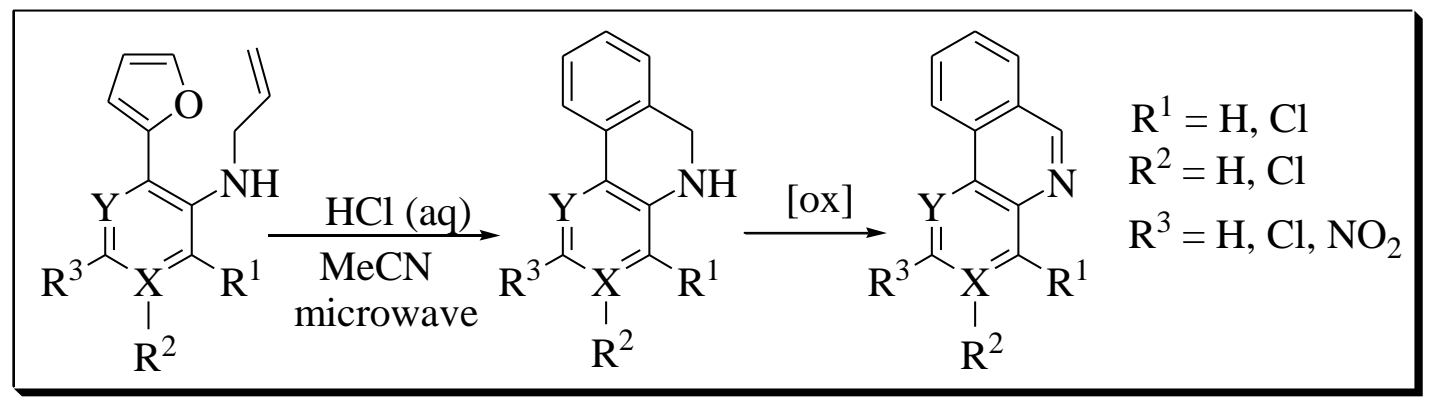

Scheme 1.4. Microwave assisted synthesis of phenanthridine derivatives.

Although these methods showed their own advantages, they generally involved either multistep processes with low yield, or starting materials which are not readily available or requirement of prefunctionalization. So, development of an efficient and convenient synthetic methodology is highly desirable.

\section{Results and discussion}

In the previous chapter we have used $o$-bromobenzyl alcohols and its analogues with 2hydroxyphenylboronic acid for the synthesis of benzo[c]chromenonesviapalladium-catalyzed domino Suzuki-Miyaura cross coupling and oxidative lactonization. Here we have substituted 2hydroxyphenylboronic acid with 2-aminophenylboronic acid. Our investigation started with our endeavor to get the optimal reaction condition.

Table 1 Screening of the reaction condition $^{\mathrm{a}}$ 


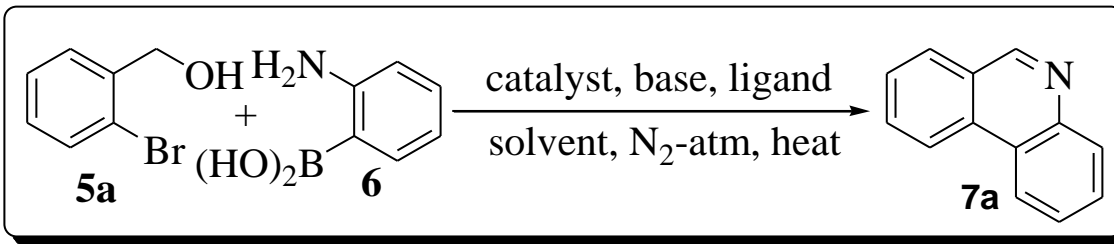

\begin{tabular}{|c|c|c|c|c|c|c|c|}
\hline Entry & Catalyst & Base & Ligand & Solvent & Temp $\left({ }^{0} \mathrm{C}\right)$ & Time (h) & Yield $(\%)^{\mathrm{b}}$ \\
\hline 1 & $\mathrm{PdCl}_{2}$ & $\mathrm{Na}_{2} \mathrm{CO}_{3}$ & $\mathrm{PPh}_{3}$ & DMF & 90 & 12 & 61 \\
\hline 2 & $\mathrm{PdCl}_{2}$ & $\mathrm{Na}_{2} \mathrm{CO}_{3}$ & $\mathrm{PPh}_{3}$ & DMF & 110 & 10 & 59 \\
\hline 3 & $\mathrm{PdCl}_{2}$ & $\mathrm{Na}_{2} \mathrm{CO}_{3}$ & $\mathrm{PPh}_{3}$ & DMF & 70 & 12 & 53 \\
\hline 4 & $\mathrm{Pd}\left(\mathrm{PPh}_{3}\right)_{4}$ & $\mathrm{Na}_{2} \mathrm{CO}_{3}$ & $\mathrm{PPh}_{3}$ & DMF & 90 & 10 & 45 \\
\hline 5 & $\mathrm{Pd}_{2}(\mathrm{OAc})_{2}$ & $\mathrm{Na}_{2} \mathrm{CO}_{3}$ & $\mathrm{PPh}_{3}$ & DMF & 90 & 10 & 75 \\
\hline 6 & $\mathrm{Pd}_{2}(\mathrm{OAc})_{2}$ & $\mathrm{~K}_{2} \mathrm{CO}_{3}$ & $\mathbf{P P h}_{3}$ & DMF & 90 & 8 & 87 \\
\hline 7 & $\mathrm{Pd}_{2}(\mathrm{OAc})_{2}$ & $\mathrm{Cs}_{2} \mathrm{CO}_{3}$ & $\mathrm{PPh}_{3}$ & DMF & 90 & 9 & 82 \\
\hline 8 & $\mathrm{Pd}_{2}(\mathrm{OAc})_{2}$ & $\mathrm{Et}_{3} \mathrm{~N}$ & $\mathrm{PPh}_{3}$ & DMF & 90 & 10 & 70 \\
\hline 9 & $\mathrm{Pd}_{2}(\mathrm{OAc})_{2}$ & $\mathrm{~K}_{3} \mathrm{PO}_{4}$ & $\mathrm{PPh}_{3}$ & DMF & 90 & 8 & 81 \\
\hline 10 & $\mathrm{Pd}_{2}(\mathrm{OAc})_{2}$ & $\mathrm{~K}_{2} \mathrm{CO}_{3}$ & $\mathrm{PCy}_{3}$ & $\mathrm{DMF}$ & 90 & 9 & 85 \\
\hline 11 & $\mathrm{Pd}_{2}(\mathrm{OAc})_{2}$ & $\mathrm{~K}_{2} \mathrm{CO}_{3}$ & - & DMF & 90 & 18 & - \\
\hline 12 & $\mathrm{Pd}_{2}(\mathrm{OAc})_{2}$ & $\mathrm{~K}_{2} \mathrm{CO}_{3}$ & $\mathrm{PPh}_{3}$ & $\mathrm{CH}_{3} \mathrm{CN}$ & 90 & 10 & 49 \\
\hline 13 & $\mathrm{Pd}_{2}(\mathrm{OAc})_{2}$ & $\mathrm{~K}_{2} \mathrm{CO}_{3}$ & $\mathrm{PPh}_{3}$ & Dioxane & 90 & 10 & 63 \\
\hline 14 & $\mathrm{Pd}_{2}(\mathrm{OAc})_{2}$ & $\mathrm{~K}_{2} \mathrm{CO}_{3}$ & $\mathrm{PPh}_{3}$ & $\mathrm{H}_{2} \mathrm{O}$ & 90 & 24 & - \\
\hline
\end{tabular}

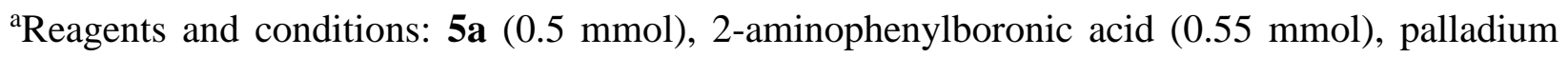
catalyst (10 mol \%), base (1.5 equiv), ligand ( 0.25 equiv) and solvent ( $3 \mathrm{~mL}), \mathrm{N}_{2}$.

${ }^{b}$ Isolated yield after purification through column chromatography.

Initially 5a was allowed to react with $\mathbf{6}$ in presence of $\mathrm{PdCl}_{2}$ catalyst, sodium carbonate base, $\mathrm{PPh}_{3}$ ligand and $\mathrm{DMF}$ as solvent at $90{ }^{\circ} \mathrm{C}$. Then temperature, catalyst, base, ligand and solvent were varied successively in order to get the optimized reaction condition. The optimal condition was found to be $\mathrm{Pd}(\mathrm{OAc})_{2}$-catalyst, $\mathrm{K}_{2} \mathrm{CO}_{3}$ base, $\mathrm{PPh}_{3}$ ligand, and $\mathrm{DMF}$ solvent at $90{ }^{\circ} \mathrm{C}$. 
With this optimized condition, the methodology was generalized towards the synthesis of various substitutedphenanthridines (Table 2)

Table 2 Synthesis of phenanthridines ${ }^{\text {a }}$

Entry

aReagents and conditions: 5a-e (0.5 mmol), 2-aminophenylboronic acid (0.55 mmol), $\mathrm{Pd}(\mathrm{OAc})_{2}(10 \mathrm{~mol} \%), \mathrm{K}_{2} \mathrm{CO}_{3}$ (1.5 equiv), $\mathrm{PPh}_{3}\left(0.25\right.$ equiv) and $\mathrm{DMF}(3 \mathrm{~mL}), \mathrm{N}_{2}$.

${ }^{\mathrm{b}}$ Isolated yield after purification through column chromatography.

As a course of mechanistic explanation, it can be postulated that Suzuki-Miyaura cross-coupling occurs first, followed by oxidation of the benzylic alcohol group to aldehyde. Then condensation is followed. Isolation of the intermediate and more studies are underway to know the exact pathway 


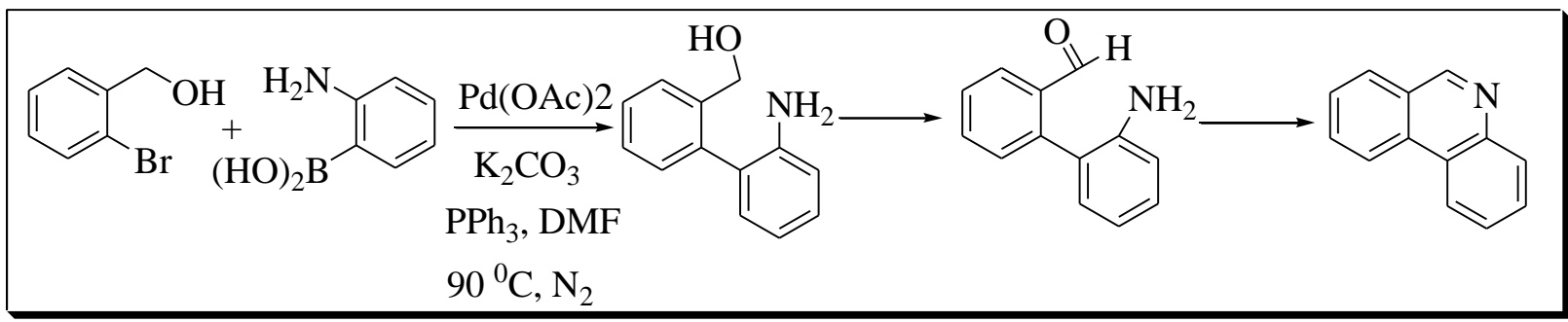

Scheme 2 Plausible rationale for the formation phenathridines

\section{Conclusion:}

In summary we have developed a short and convenient methodology for the synthesis of phenanthridines from readily available starting material. Our methodology will be helpful towards the synthesis of substituted phenanthridine derivatives which can be further used for important pharmaceutical and material applications.

\section{References:}

1. Nakanishi, T.; Suzuki, M., Revision of the Structure of Fagaridine Based on the Comparison of UV and NMR Data of Synthetic Compounds. Journal of Natural Products 1998, 61 (10), 1263-1267.

2. Ghosh, M.; Ray, J. K., Ten years advancement in the synthetic applications of 2-bromocyclohexenecarbaldehydes and 2-bromobenzaldehydes and derived substrates under palladiumcatalyzed cross-coupling conditions. Tetrahedron 2017, 73 (27), 3731-3799.

3. Brahma, S.; Ray, J. K., Halovinyl aldehydes: useful tools in organic synthesis. Tetrahedron 2008, 64 (13), 2883-2896.

4. Brahma, S.; Ray, P.; Singha, R.; Ray, J. K., Visible Colourimetric and Ratiometric Fluorescent Chemosensors for Cu (II) and Ni (II) Ions. Asian Journal of Chemistry 2016, 28 (5), 1035.

5. Chaudhuri, S.; Maity, S.; Roy, M.; Ray, P.; Ray, J. K., A Vinyl Radical Cyclization Route to Hydroxycyclohexene Fused Carbocycles. Asian Journal of Chemistry 2016, 28 (1).

6. Ghosh, M.; Ray, J. K., Ten years advancement in the synthetic applications of 2-bromocyclohexenecarbaldehydes and 2-bromobenzaldehydes and derived substrates under palladiumcatalyzed cross-coupling conditions. Tetrahedron 2017, 73 (27-28), 3731-3799.

7. Jana, R.; Chatterjee, I.; Samanta, S.; Ray, J. K., Novel and rapid palladium-assisted 6pi electrocyclic reaction affording 9,10-dihydrophenanthrene and its analogues. Org Lett 2008, 10 (21), 4795-7. 
8. Jana, R.; Samanta, S.; Ray, J. K., Substrate dependent intramolecular palladiumcatalysed cyclisation and subsequent $\beta-\mathrm{H}$ elimination or $\mathrm{C}-\mathrm{H}$ activation: a general method for the synthesis of fused pyran rings. Tetrahedron Letters 2008, 49 (5), 851-854.

9. Liu, J.; Liu, W.; Weitzhandler, I.; Bhattacharyya, J.; Li, X.; Wang, J.; Qi, Y.; Bhattacharjee, S.; Chilkoti, A., Ring-Opening Polymerization of Prodrugs: A Versatile Approach to Prepare Well-Defined Drug-Loaded Nanoparticles. Angewandte Chemie International Edition 2015, 54 (3), 1002-1006.

10. Mal, S. K.; Ray, D.; Ray, J. K., Palladium-catalyzed tandem oxidative cyclization of 1bromohexa-1,5-dien-3-ols: easy access to cyclopentenones. Tetrahedron Letters 2004, 45 (2), 277-279.

11. Nandi, S.; Singha, R.; Ray, J. K., Palladium catalyzed intramolecular cascade type cyclizations: Interesting Approach towards naphthoquinone derivatives having an O-containing heterocyclic skeleton. Tetrahedron 2015, 71 (4), 669-675.

12. Nandi, S.; Singha, R.; Samanta, S.; Ray, J. K., Synthesis of pentalongin and C (1)-and C (3)-substituted pentalongin using intramolecular Heck reaction. Tetrahedron Letters 2012, 53 (21), 2659-2661.

13. Paul, S.; Samanta, S.; Ray, J. K., Palladium-catalyzed one-pot Suzuki coupling followed by arylpalladium addition to aldehyde: A convenient route to fluoren-9-one derivatives. Tetrahedron Letters 2010, 51 (42), 5604-5608.

14. Ray, D.; Mal, S. K.; Ray, J. K., Palladium-Catalyzed Novel Cycloisomerization: An Unprecedented Domino Oxidative Cyclization towards Substituted Carbocycles. Synlett 2005, 2005 (14), 2135-2140.

15. Ray, D.; Nasima, Y.; Sajal, M. K.; Ray, P.; Urinda, S.; Anoop, A.; Ray, J. K., Palladium-Catalyzed Intramolecular Oxidative Heck Cyclization and Its Application toward a Synthesis of ( \pm - $\beta$-Cuparenone Derivatives Supported by Computational Studies. Synthesis 2013, 45 (09), 1261-1269.

16. Ray, D.; Ray, J. K., Novel Synthetic Approach Toward ( \pm )- $\beta$-Cuparenone via PalladiumCatalyzed Tandem Heck Cyclization of 1-Bromo-5-methyl-1-aryl-hexa-1, 5-dien-3-ol Derivatives. Organic letters 2007, 9 (2), 191-194.

17. Ray, J. K., Stereoselective Synthesis of Bioactive Compounds (Track) Use of "halo vinyl aldehydes" in organic synthesis and chemo selective functional group transformations in gamma lactam derivatives.

18. Ray, J. K.; Paul, S.; Ray, P.; Singha, R.; Rao, D. Y.; Nandi, S.; Anoop, A., Pdcatalyzed intramolecular sequential Heck cyclization and oxidation reactions: a facile pathway for the synthesis of substituted cycloheptenone evaluated using computational studies. New Journal of Chemistry 2017, 41 (1), 278-284.

19. Ray, J. K.; Singha, R.; Ray, D.; Ray, P.; Rao, D. Y.; Anoop, A., Palladium-catalyzed expedient Heck annulations in 1-bromo-1,5-dien-3-ols: Exceptional formation of fused bicycles. Tetrahedron Letters 2019, 60 (13), 931-935.

20. Roy, B. C.; Gupta, M. D.; Bhoumik, L.; Ray, J. K., Spectroscopic investigation of water-soluble polyaniline copolymers. Synthetic Metals 2002, 130 (1), 27-33.

21. Samanta, S.; Mohapatra, H.; Jana, R.; Ray, J. K., Pd (0) catalyzed intramolecular Heck reaction: a versatile route for the synthesis of 2-aryl substituted 5-, 6-, and 7-membered Ocontaining heterocycles. Tetrahedron Letters 2008, 49 (50), 7153-7156.

22. Singha, R.; Roy, S.; Nandi, S.; Ray, P.; Ray, J. K., Palladium-catalyzed one-pot Suzuki-Miyaura cross coupling followed by oxidative lactonization: a novel and efficient route 
for the one-pot synthesis of benzo[c]chromene-6-ones. Tetrahedron Letters 2013, 54 (7), 657660.

23. Brahma, S.; Ray, J. K., Halovinyl aldehydes: useful tools in organic synthesis. Tetrahedron 2008, 13 (64), 2883-2896.

24. Sarkar, P.; Ahmed, A.; Ray, J. K., Suzuki cross coupling followed by cross dehydrogenative coupling: An efficient one pot synthesis of Phenanthrenequinones and analogues. Tetrahedron Letters 2020, 61 (13), 151701.

25. Ray, P.; Gidley, D.; Badding, J. V.; Lueking, A. D., UV and chemical modifications of polymer of Intrinsic Microporosity 1 to develop vibrational spectroscopic probes of surface chemistry and porosity. Microporous and Mesoporous Materials 2019, 277, 29-35.

26. Ray, P.; Xu, E.; Crespi, V. H.; Badding, J. V.; Lueking, A. D., In situ vibrational spectroscopy of adsorbed nitrogen in porous carbon materials. Physical Chemistry Chemical Physics 2018, 20 (22), 15411-15418.

27. Ray, P.; Gray, J. L.; Badding, J. V.; Lueking, A. D., High-Pressure Reactivity of Triptycene Probed by Raman Spectroscopy. The Journal of Physical Chemistry B 2016, 120 (42), 11035-11042.

28. Ray, P., Interactions of nitrogen and hydrogen with various $1 \mathrm{D}$ and $3 \mathrm{D}$ carbon materials probed via in-situ vibrational spectroscopy. Ph. D. Thesis 2016.

29. Wang, C.-Y.; Ray, P.; Gong, Q.; Zhao, Y.; Li, J.; Lueking, A. D., Influence of gas packing and orientation on FTIR activity for $\mathrm{CO}$ chemisorption to the $\mathrm{Cu}$ paddlewheel. Physical Chemistry Chemical Physics 2015, 17 (40), 26766-26776.

30. Jayanta, R.; Leena, B., Spectroscopic Investigation of Polyaniline Co Poly Meta Amino Benzene Sulfonic Acid. 2021.

31. Ray, J.; Bhowmik, L., Sol Gel Technique to Prepare Composite Material of Glass-DyePolymers. 2021.

32. Ray, J.; Bhowmik, L., Preparation and Evaluation of Novel Bamboo-Polymer Composites. 2021.

33. Ray, P.; Ferraro, M.; Haag, R.; Quadir, M., Dendritic Polyglycerol-Derived NanoArchitectures as Delivery Platforms of Gemcitabine for Pancreatic Cancer. Macromol Biosci 2019, 19 (7), e1900073.

34. Das, A.; Haque, I.; Ray, P.; Ghosh, A.; Dutta, D.; Quadir, M.; De, A.; Gunewardena, S.; Chatterjee, I.; Banerjee, S.; Weir, S.; Banerjee, S. K., CCN5 activation by free or encapsulated EGCG is required to render triple-negative breast cancer cell viability and tumor progression. Pharmacol Res Perspect 2021, 9 (2), e00753.

35. Ray, P.; Haideri, N.; Haque, I.; Mohammed, O.; Chakraborty, S.; Banerjee, S.; Quadir, M.; Brinker, A. E.; Banerjee, S. K., The Impact of Nanoparticles on the Immune System: A Gray Zone of Nanomedicine. Journal of Immunological Sciences 2021, 5 (1).

36. Ray, P.; Dutta, D.; Haque, I.; Nair, G.; Mohammed, J.; Parmer, M.; Kale, N.; Orr, M.; Jain, P.; Banerjee, S.; Reindl, K. M.; Mallik, S.; Kambhampati, S.; Banerjee, S. K.; Quadir, M., pH-Sensitive Nanodrug Carriers for Codelivery of ERK Inhibitor and Gemcitabine Enhance the Inhibition of Tumor Growth in Pancreatic Cancer. Molecular Pharmaceutics 2021, 18 (1), 87-100.

37. Ray, P.; Kale, N.; Quadir, M., New side chain design for pH-responsive block copolymers for drug delivery. Colloids and Surfaces B: Biointerfaces 2021, 200, 111563.

38. Abdullah, C. S.; Ray, P.; Alam, S.; Kale, N.; Aishwarya, R.; Morshed, M.; Dutta, D.; Hudziak, C.; Banerjee, S. K.; Mallik, S.; Banerjee, S.; Bhuiyan, M. S.; Quadir, M., Chemical 
Architecture of Block Copolymers Differentially Abrogate Cardiotoxicity and Maintain the Anticancer Efficacy of Doxorubicin. Molecular Pharmaceutics 2020, 17 (12), 4676-4690.

39. Clément, M.; Abdellah, I.; Ray, P.; Martini, C.; Coppel, Y.; Remita, H.; Lampre, I.; Huc, V., Synthesis and NMR study of trimethylphosphine gold(i)-appended calix[8]arenes as precursors of gold nanoparticles. Inorganic Chemistry Frontiers 2020.

40. Confeld, M. I.; Mamnoon, B.; Feng, L.; Jensen-Smith, H.; Ray, P.; Froberg, J.; Kim, J.; Hollingsworth, M. A.; Quadir, M.; Choi, Y.; Mallik, S., Targeting the tumor core: hypoxiaresponsive nanoparticles for delivery of chemotherapy to pancreatic tumors. Molecular Pharmaceutics 2020.

41. Sarker, N. C.; Ray, P.; Pfau, C.; Kalavacharla, V.; Hossain, K.; Quadir, M., Development of Functional Nanomaterials from Wheat Bran Derived Arabinoxylan for Nucleic Acid Delivery. Journal of Agricultural and Food Chemistry 2020, 68 (15), 4367-4373.

42. Ray, P.; Confeld, M.; Borowicz, P.; Wang, T.; Mallik, S.; Quadir, M., PEG-b-poly (carbonate)-derived nanocarrier platform with $\mathrm{pH}$-responsive properties for pancreatic cancer combination therapy. Colloids and Surfaces B: Biointerfaces 2019, 174, 126-135.

43. Ray, P.; Nair, G.; Ghosh, A.; Banerjee, S.; Golovko, M. Y.; Banerjee, S. K.; Reindl, K. M.; Mallik, S.; Quadir, M., Microenvironment-sensing, nanocarrier-mediated delivery of combination chemotherapy for pancreatic cancer. Journal of Cell Communication and Signaling 2019.

44. Ray, P.; Alhalhooly, L.; Ghosh, A.; Choi, Y.; Banerjee, S.; Mallik, S.; Banerjee, S.; Quadir, M., Size-Transformable, Multifunctional Nanoparticles from Hyperbranched Polymers for Environment-Specific Therapeutic Delivery. ACS Biomaterials Science \& Engineering 2019, 5 (3), 1354-1365.

45. Ghosh, A.; Sarkar, S.; Ghosh, S.; Ray, P.; Quadir, M.; Banerjee, S. K.; Banerjee, S., Abstract 1234: Zoledronic acid-induced suppression of invasive phenotypes of pancreatic cancer cells is mediated through downregulation of CYR61/CCN1. Cancer Research 2019, 79 (13 Supplement), 1234.

46. Ray, P.; Clément, M.; Martini, C.; Abdellah, I.; Beaunier, P.; Rodriguez-Lopez, J.-L.; Huc, V.; Remita, H.; Lampre, I., Stabilisation of small mono- and bimetallic gold-silver nanoparticles using calix[8]arene derivatives. New Journal of Chemistry 2018, 42 (17), 1412814137.

47. André, E.; Boutonnet, B.; Charles, P.; Martini, C.; Aguiar-Hualde, J. M.; Latil, S.; Guérineau, V.; Hammad, K.; Ray, P.; Guillot, R.; Huc, V., A New, Simple and Versatile Strategy for the Synthesis of Short Segments of Zigzag-Type Carbon Nanotubes. Chemistry 2016, 22 (9), 3105-14.

48. $\quad$ Babak, K.; Torabi, M.; Foad, K.; Priyanka, R., Novel $\beta$-Cyclodextrin Functionalized Core-Shell Fe3O4 Magnetic Nanoparticles for the Removal of Toxic Metals from Water. 2021.

49. Read, M. L.; Gundersen, L.-L., Synthesis of Phenanthridine Derivatives by MicrowaveMediated Cyclization of o-Furyl(allylamino)arenes. The Journal of Organic Chemistry 2013, 78 (3), 1311-1316. 